\title{
A review of the book:
}

M. Chmaj, W. Skrzydło, System wyborczy w Rzeczypospolitej Polskiej [The Election System in the Republic of Poland], Wolters Kluwer Polska - LEX, Warsaw 2011, pp. 182.

by Joanna Marszatek-Kawa

In 2011, the long-awaited fourth issue of the book System wyborczy w Rzeczypospolitej Polskiej was published by the Lex publishing house. The issue includes the codification of election law, which was enacted in 2011.The authors of the presented issue are two outstanding Polish constitutionalists.

WiesławSkrzydło holds an honorary doctorate of the I. Franco University in Lviv and used to be a prorector of the Maria Curie-Skłodowska University in Lublin. He is also a long-standing chief editor of Przeglad Sejmowy [Sejm Review] and quite a new publication - Przeglad Prawa Konstytucyjnego [Review of Constitutional Law]. W. Skrzydło published several dozen monographs, such as: $O$ partii i systemach partyjnych [About party and party systems], Ustrój polityczny
PRL [Political system in the People's Republic of Poland], Ustrój polityczny Francji [Political system in France], Konstytucja Rzeczypospolitej Polskiej. Komentarz [Constitution of the Republic of Poland. A Comment], Ustrój polityczny RP w świetle Konstytucji z 1937 roku [Political system in the Republic of Poland in the light of the Constitution of 1937], Leksykonwiedzy o państwie i konstytucji [Lexicon of knowledge about state and constitution]. He is also a co-author and editor of over 200 works, including: Ustrój istruktura aparatu państwowego i samorzadu terytorialnego (Political system and structure of state apparatus and local authority), Prawo konstytucyjne [Constitutional Law], Polskie prawo konstytucyjne [Polish constitutional law], Ustroje państw 
wspótczesnych [Political systems of modern countries].

MarekChmaj is an author or co-author of over 200 publications about broadly defined constitutional systems in the Republic of Poland. He is also an editor of several dozen other works. In addition, MrSkrzydło performs the function of an expert in Sejm and Senate of the Republic of Poland as well as in the Institute of Public Affairs.

It is worth mentioning that in the Third Republic of Poland, before enacting the Electoral Code ${ }^{1}$ thereexisted several electoral regulations. In practice, on the Polish political scene, the electoral law has been changed most often and with great enthusiasm, especially before each approaching election. Some of the electoral regulations were used only once. In addition, the enthusiasm for reforms was usually caused by the interest of a particular political party. As a result, there were more and more adherents of the opinion that the entire electoral material should be thoroughly regulated in one legal act. This view was expressed among others by: Jerzy Buczkowski, Krzysztof Skotnicki, Arkadiusz Żukowski.

1 The Act of 5th January 2011Electoral Code, Journal of Laws No. 21, item 112. The President of the Republic of Poland signed the Act on 19th January2011 See: „Przegląd Prawa Konstytucyjnego” (The Review of constitutional law) no. 3(7)/2011, Torun 2011. See also: The Act of 5th January 2011, Implementing provisions to the actElectoral Code, (Journal of Laws, no. 21, item 113).
The works on the Code in the parliamentary Extraordinary Committee for Electoral Law have been taking place since 2009. After many lively discussions among constitutionalists, supported by the Institute of Public Affairs, on $1^{\text {st }}$ August 2011 a new legislative act came into force. The act regulates the election procedure in Poland ${ }^{2}$. The aim of the new regulation is to stabilize ${ }^{3}$ and modernize Polish election

2 However, there were some problems. The Electoral Code had been amended many time before coming into force. See also: 1 . The amendment of the Act of 3rd February 2011 (Journal of Laws No. 26, item 134), 2. The amendment of 1st April 2011 (Journal of Laws No. 94, item 550), 3.The amendment of 15thApril 2011 (Journal of Laws No. 102, item 588) and 4.The amendment of 27th May 2011 (Journal of Laws No. 147, item 881).Moreover, the constitutionality of many provisions of the Code was evaluated by the Constitutional Tribunal, which investigated among others the issues of: the term of vacatiolegis of the new regulation, voting by Proxy and correspondence voting, the prohibition of using, by electoral staff, billboards bigger than $2 \mathrm{~m}^{2}$, paid electoral commercials on TV and radio, FPPs.See: the decision of Constitutional Tribunal of20th July 2011 (K 9/11, Journal of Laws No. 149, item 889). According to the judges of the Constitutional Tribunal the following regulations of the Electoral Code were unconstitutional:the possibility of organizing 2-days elections to Sejm and Senate and presidential elections, the prohibition of using large-format billboards during campaigns and the prohibition of using paid electoral commercials on TV and radio. The Constitutional Tribunal decided also that the provisions of the Implementing Provisions to the act Electoral Code that allowed introducing the new code regulation at the time of announcing elections were against the Constitution of the Republic of Poland.

3 More widely: A. Rakowska, K. Skotnicki, Ko- 
law (e.g. they created 100 one-mandate electoral districts during the elections to the Senat of the Republic of Poland, as a possibility of correspondence voting for Poles living abroad, the possibility to vote by proxy for voters who are disabled or over 75 years-old, unified opening hours of polling stations, the procedures of financing the electoral campaigns were set) ${ }^{4}$.

It is worth mentioning that the fact of adopting the Electoral Code ${ }^{5}$ is without doubt a positive change, however, according to many representatives of the doctrine, the legislator didn't manage to avoid defects. It was a mistake that the legislator didn't adopt many postulates presented before, concerning the reform of election law. For example, the central voters register, similar to the one used in other European countries, was not introduced. According to Piotr Uziębło, apart from the issues regulated by the Code there are still

deks wyborczy jako szansa na stabilizacje prawa wyborczego, [w:] Księga pamiątkowa z okazji obchodów 20-lecia wolnych wyborów w Polsce, Warsaw2011, pp. 107-120.

${ }^{4}$ See: J. Zbieranek, Kodeks wyborczy: We wszystkich wyborach będą jednolite zasady głosowania, „Gazeta prawna” of 16th February 2011, http://prawo.gazetaprawna.pl/artykuly/487592, kodeks_wyborczy_we_wszystkich_wyborach_ beda_jednolite_zasady_glosowania.html?utm_source=feedburner\&utm_medium =feed\&utm_campaign $=$ Feed $\% 3 \mathrm{~A}+$ GazetaPrawna-Prawo + (Gazeta +Prawna+-+Prawo+i+wymiar+sprawiedliwosci).

${ }^{5}$ From latinword codex which means a book, a collection of laws. many other important aspects related to the organization of elections. Such issues as political parties and referendums should have been included in the new act. In the second place, P. Uziębło mentions that many of the adopted solutions were moved to the Code without any serious, substantial discussion. Nevertheless, the new Electoral Code increases "the transparency of Polish electoral problems"6.

The fact of enacting the Electoral Code changed and organized existing Polish electoral law. Therefore, the study prepared by M. Chmaj and W. Skrzydło entitled System wyborczy w Rzeczypospolitej Polskiej is so important and necessary.

What is important for each reader the layout of the reviewed book is transparent and clear. The design and the composition of chapters are coherent and logical. The reviewed work consists of nine parts. In the first chapter the Authors presented in a general way the issues related to direct and representative democracy. The subjects raised in this chapter concern among other issues related to the functions of elections and seats. The functions of elections as well as representative seats were also described in this part of the work. The second chapter is a detailed exposition about the rules of Polish electoral law (i.e. the rules of universality, equality, directness, confiden-

6 P. Uziębło, Wprowadzenie do Kodeksu wyborczego, „Przegląd Prawa Konstytucyjnego” 2011, no. $3(7) / 2011$, p. 7. 
tiality of voting, plurality and proportional voting systems). In the third chapter of the study the Authors elaborate on all the issues related to the organization of elections and voting, electoral protests, electoral administration and the rules of financing electoral campaigns. The analysis of the electoral system for the Polish Sejm and Senate can be found in chapters IV and V. In the chapters from sixth to ninth, the reader can find the description of presidential elections, elections to the European Parliament and local authorities as well as elections of village mayor, mayor and president of a city.

The reviewed work was published in the academic series of Lex a Wolters Kluwer business publishing house. Nevertheless, some readers can feel a need to see the evaluation of the new code regulation, which was not included in this work. In addition, the Authors of this work, as wellknown experts in the area of law, presented their opinions about the Code on many different occasions. I believe that, in the next edition of this book, it would be a good idea to explain in more detail the opinions of other representatives of the doctrine. It can be interesting due to the fact that our perspective has changed and we are now able to criticize a practical adaptation of the new electoral act.

As mentioned before, the asset of this publication is the fact that the presented information is very up-to-date. Another asset is the impressing bibliography used by the Authors. It should also be emphasized that the bibliography used in a given part of the monograph can be found at the end of each chapter.

The reviewed book has also another indisputable value - the language used by the researchers is simple and matter-offact, without any academic jargon. It is also important that this type of narration does not invalidate the work in any manner. Just the opposite, the authors were able to explain complicated legal issues in a very approachable way. This is why the experts on the subject should find System wyborczy w Rzeczypospolitej Polskiej really interesting. It can also be attractive for readers who are interested in the Polish political scene. The presented monograph constitutes an up-to-date and clear digest of information on elections in Poland, which can be used by academics, politicians, journalists, publicists as well as by students interested in the mentioned issues.

In my opinion, System wyborczy $w$ Rzeczypospolitej Polskiej is a successful attempt at presenting the issues concerning elections in Poland. To sum up, the book is cognitively valuable and integrates into the existing literature on the subject, completing it in a serious manner. It is also simply a very interesting book. 